\title{
OPTIMIZATION OF RED PIGMENT PRODUCTION BY MONASCUS PURPUREUS FTC 5356 USING RESPONSE SURFACE METHODOLOGY
}

\author{
NOR FARHANA HAMId AND FARHAN MOHD SAID* \\ Faculty of Chemical and Natural Resources Engineering, Universiti Malaysia Pahang, \\ Lebuhraya Tun Razak, 26300 Kuantan, Pahang, Malaysia. \\ *Corresponding author: farhan@ump.edu.my
}

(Received: 20 $0^{\text {th }}$ Feb 2017; Accepted: 23 ${ }^{\text {rd }}$ Feb 2018; Published on-line: $1^{\text {st }}$ June 2018)

https://doi.org/10.31436/iiumej.v19i1.814

\begin{abstract}
Factors such as environmental conditions and nutrients are significant for successful growth and reproduction of microorganisms. Manipulations of the factors are the most effective way to stimulate the growth of the microorganism, which can be used to optimize the yield of a product. In this study, Central Composite Design (CCD) of Response Surface Methodology (RSM) was used to optimize the production of red pigment by Monascus purpureus FTC 5356 using the petioles of oil palm fronds (OPF) as a substrate in solid state fermentation (SSF). The data was analyzed using Design Expert Software. The optimum combination predicted via RSM was confirmed through experimental work. The interactions between three variables such as initial moisture content $(\%)$, initial $\mathrm{pH}$ value $(\mathrm{pH})$, and peptone concentration $(\%)$ were studied and modelled. The statistical analysis of the results showed that the optimal conditions for red pigment production $47 \mathrm{AU} / \mathrm{g}$ with the biomass of $425.1 \mathrm{mg} / \mathrm{g}$ was at $55 \%$ initial moisture content, $3 \%$ of peptone, and at $\mathrm{pH} 3$. The RSM results showed that the initial $\mathrm{pH}$ value had a significant effect on red pigment production $(\mathrm{P}-\mathrm{value}<0.05)$. The validation of these results was also conducted by fermentation with predicted conditions and it was found that there was a discrepancy of $0.39 \%$ between the values of the experimental result and those of the predicted values.
\end{abstract}

ABSTRAK: Keadaan persekitaran dan nutrien merupakan faktor-faktor penting dalam pertumbuhan mikroorganisma. Manipulasi faktor-faktor tersebut adalah kaedah terbaik bagi meningkatkan pertumbuhan mikroorganisma dan mengoptimumkan penghasilan produk. Kajian ini mengguna pakai Rekaan Gabungan Pusat (CCD) melalui Kaedah Tindak balas Permukaan (RSM) bagi penghasilan pigmen merah optimum oleh Monascus purpureus FTC 5356 menggunakan batang pelepah kelapa sawit (OPF) sebagai perumah dalam proses penapaian pepejal (SSF). Data telah dianalisis menggunakan perisian Design Expert. Gabungan parameter optimum seperti cadangan RSM telah disahkan secara eksperimen. Interaksi antara tiga pemboleh ubah seperti kandungan lembapan awal (\%), nilai $\mathrm{pH}$ awal $(\mathrm{pH})$, dan kepekatan pepton (\%) telah dikaji dan dimodelkan. Analisis statistik menunjukkan penghasilan optimal pigmen merah adalah pada $47 \mathrm{AU} / \mathrm{g}$ dengan biomas sebanyak $425.1 \mathrm{mg} / \mathrm{g}$, pada 55\% lembapan awal, 3\% pepton dan pada $\mathrm{pH} 3$. Hasil keputusan RSM menunjukkan $\mathrm{pH}$ awal memberikan kesan signifikan kepada penghasilan pigmen merah (nilai $\mathrm{P}<0.05$ ). Pengesahan analisis juga telah dijalankan melalui proses penapaian dan hasil ujikaji mendapati $0.39 \%$ lebih tinggi daripada nilai jangkaan.

KEYWORDS: response surface methodology; red pigment; oil palm frond; Monascus pigment 


\section{INTRODUCTION}

In recent years, colorants have been extensively used in the food industry. However, to overcome the unlimited usage of synthetic pigment, which is found to be hazardous and toxic to human health, the development of alternate sources for the production of natural pigment has been focused on. Nowadays, productions of pigment from microbial origin have attracted more attention from the food industry. Particular focus has been given to Monascus sp., which is a nontoxic fungi that has been widely used as a natural colorant and food additive in East Asia. Monascus pigment can produce three groups of pigment: orange, red, and yellow. Among these pigments, the red pigment is gaining high market demand for its use [1].

It is important to study the effect on the red pigments produced by Monascus sp. under different culture conditions, for the safe and successful application in food and pharmaceutical industries [2]. Previous study was done on the usage of petioles and leaflets of oil palm frond (OPF) as a substrate [3]. The finding revealed that $100 \%$ petiole rendered the best results. Thus, the goal of this study was to optimize the most significant of the multivariable factors for substrates made solely of petiole, in order to influence red pigment production. Factors observed include initial moisture content, peptone concentration, and initial $\mathrm{pH}$ value.

The traditional 'one factor at a time' (OFAT) approach used for optimizing a multifactor system is not only effort and time consuming, but also often misses in representing the interaction effect between different factors [4]. However, OFAT could be used as a preliminary experiment to set the range of the factor efficiently, making the results more reasonable and credible [5]. Therefore, the traditional approach of OFAT still can be applied. The range of factors obtained in OFAT can be used by adopting a statistical approach, such as response surface methodology (RSM), to solve the complexity involved in red pigment production. Recently, many types of statistical experimental design methods have been discovered for optimization [6-8]. Among them, RSM is the most suitable technique to reduce the number of experimental trials needed. It is also used to evaluate the most significant single factors and to effectively seek the optimum conditions for the multivariable system [8]. Several studies have applied RSM for optimization of red pigment [9-11]. However, to the best of our knowledge, no research has been reported on the application of RSM for optimization the red pigment production using Monascus purpureus FTC 5356 on petioles of oil palm fronds (OPF). Therefore, in order to determine the significant optimization factors in red pigment production, response surface methodology was applied in the present study.

\section{MATERIALS AND METHODS}

\subsection{Microorganism}

The strain used in this study was Monascus purpureus FTC 5356 obtained from Malaysian Agricultural Research and Development Institute, Serdang, Malaysia. The stock culture was maintained on potato dextrose agar (PDA) media and incubated at $28-30{ }^{\circ} \mathrm{C}$ for 7 days, preserved at $4{ }^{\circ} \mathrm{C}$ and sub-cultured once every 4 weeks [12].

\subsection{Inoculum Preparation}

Monascus purpureus FTC 5356 was grown on PDA slants at $30{ }^{\circ} \mathrm{C}$ for 7 days. The spores were then scrapped off and suspended in $5 \mathrm{ml}$ sterile distilled under aseptic conditions at room temperature. The suspension was adjusted to $10^{8}$ spores $/ \mathrm{ml}$ with sterile distilled 
water. The spore numbers were counted using a Neubauer hemacytometer (Cole-Parmer 79001-00). The adjusted spore suspension (10\% v/w) was used for further solid state fermentation [12].

\subsection{Substrate Preparation}

Fresh oil palm fronds (OPF) were obtained from the Federal Land Development Authority (FELDA) Bukit Goh, Kuantan, Pahang. The leaflets and petioles were separated from the OPF. The petioles were then cut into small pieces approximately $3-4 \mathrm{~cm}$ in length, washed, and dried at $60{ }^{\circ} \mathrm{C}$ for 3 days. The dried petiole was shredded and ground using a commercial grinder (Retsch ZM-200, Germany) to a particle size smaller than $1 \mathrm{~mm}$ by passing through $1 \mathrm{~mm}$ sieve screens using a vibrator sieve shaker (Retsch, Germany).

\subsection{Solid State Fermentation}

The experimental work was done based on the experimental design being set by Design Expert (Version 7.1.6, 2008, Minneapolis MN, USA), (Table 1 and Table 2). The best range of each factor was selected by applying the One Factor at A Time (OFAT) method as in the preliminary experiment (data not shown). All experiments have been carried out in replicates and the whole flasks were discarded. Each substrate was inoculated and incubated in the dark at $30^{\circ} \mathrm{C}$ for 8 days.

Table 1: Independent variables, responses and the levels in the experimental design.

\begin{tabular}{cclccc}
\hline No & Designation & Factors & $\mathbf{- 1}$ & $\mathbf{0}$ & $\mathbf{+ 1}$ \\
\hline 1 & $\mathrm{X}_{1}$ & Initial moisture content $(\%)$ & 40 & 55 & 70 \\
2 & $\mathrm{X}_{2}$ & Peptone concentration $(\%)$ & 2 & 35 & 5 \\
3 & $\mathrm{X}_{3}$ & Initial pH value & 6 & 8 & 10 \\
\cline { 2 - 6 } & & Response & & & \\
4 & $\mathrm{Y}_{1}$ & Red pigment production $(\mathrm{AU} / \mathrm{g})$ & & & \\
5 & $\mathrm{Y}_{2}$ & Biomass $(\mathrm{mg} / \mathrm{g})$ & & & \\
6 & $\mathrm{Y}_{3}$ & Glucose concentration $(\mu \mathrm{g} / \mathrm{g})$ & & & \\
\hline
\end{tabular}

Table 2: The central composite design matrix developed for three independent variables

\begin{tabular}{cccc}
\hline Run & $\mathbf{X}_{\mathbf{1}}$ & $\mathbf{X}_{\mathbf{2}}$ & $\mathbf{X}_{\mathbf{3}}$ \\
\hline 1 & 0 & 0 & -1 \\
2 & -1 & -1 & -1 \\
3 & +1 & -1 & -1 \\
4 & -1 & +1 & -1 \\
5 & +1 & +1 & -1 \\
6 & 0 & 0 & 0 \\
7 & -1 & 0 & 0 \\
8 & 0 & 0 & 0 \\
9 & 0 & 0 & 0 \\
10 & 0 & 0 & 0 \\
11 & +1 & 0 & 0 \\
12 & 0 & +1 & 0 \\
13 & 0 & -1 & 0 \\
14 & +1 & -1 & +1 \\
15 & +1 & +1 & +1 \\
16 & 0 & 0 & +1 \\
17 & -1 & +1 & +1 \\
18 & -1 & -1 & +1 \\
\hline
\end{tabular}




\subsection{Pigment Extraction and Determination}

The harvested fermented solid was dried at $60{ }^{\circ} \mathrm{C}$ for 24 hours in an oven (Memmert UFB-500). The dried fermented solid was extracted with $95 \%$ ethanol in a ratio of 1:10 w/v for 1 hour at $200 \mathrm{rpm}$, in an incubator shaker (Infors AG-CH-4103 Bottmingen). The extract was then allowed to stand for $15 \mathrm{~min}$, and filtered through Whatman No.1 filter paper. Ethanol extracts of unfermented substrates were used as blanks. Analysis of pigment concentration was done using a UV-Vis spectrophotometer (Hitachi U-1800). The wavelength used was $500 \mathrm{~nm}$. Pigment yield was expressed as absorbance units (AU) per gram of dried solids [12-14].

\subsection{Reducing Sugar Determination}

Reducing sugar was measured using a dinitrosalicylic acid (DNS) method $[12,15]$. The reducing sugar was measured at $575 \mathrm{~nm}$ by UV-Vis spectrophotometer (Hitachi U-1800).

\subsection{Biomass (Cell Dry Weight)}

Total fungal biomass was determined by measuring the $\mathrm{N}$-acetylglucosamine released by acid hydrolysis of the chitin present in the fungal cell walls. The acid hydrolysis of the sample was carried out by mixing $0.5 \mathrm{~g}$ of dry fermented OPF powder with $2 \mathrm{ml}$ of $60 \%$ (vol/vol) sulfuric acid, $\mathrm{H}_{2} \mathrm{SO}_{4}$ and the mixture was incubated at $25{ }^{\circ} \mathrm{C}$ in a fume hood for 24 $\mathrm{h}$ [16]. Then the mixture was diluted with distilled water to make a $1 \mathrm{~N}$ solution of sulfuric acid that was then autoclaved at $121{ }^{\circ} \mathrm{C}$ for $1 \mathrm{~h}$. The mixture was allowed to cool at room temperature and neutralized with $5 \mathrm{~N} \mathrm{NaOH}$ to $\mathrm{pH} 7$ and the final volume was brought up to $60 \mathrm{ml}$ with deionized water. Later, the filtered acid hydrolysis sample $(1 \mathrm{ml})$ was mixed with $1 \mathrm{ml}$ of acetyl acetone reagent $(2 \%$ ( $\mathrm{vol} / \mathrm{vol})$ of acetyl acetone in $1 \mathrm{~N}$ sodium bicarbonate $\left(\mathrm{Na}_{2} \mathrm{CO}_{3}\right)$ before being placed in a boiling water bath for $20 \mathrm{~min}$ [12]. After cooling, $6 \mathrm{ml}$ of ethanol (95\%) was added, followed by $1 \mathrm{ml}$ of Ehrlich reagent $(2.67 \%$ (w/v) of $p$-dimethylaminobenzaldehyde (Merck) in 1:1 mixture of ethanol and concentrated hydrochloric acid) [17]. The mixture was incubated in a water bath at $65{ }^{\circ} \mathrm{C}$ for $10 \mathrm{~min}$. After cooling, the optical density was read at $530 \mathrm{~nm}$ against the reagent blank, Nacetylglucosamine (Sigma-Aldrich) as the external using a UV-visible spectrophotometer $[12,18]$.

\subsection{Experimental Design}

The red pigment production was developed and optimized using response surface methodology (RSM) provided by Design Expert Software (Version 7.1.6, 2008, Minneapolis MN, USA). A standard RSM design tool known as Central Composite Design (CCD) was applied to study the significant production factor of red pigment. The three identified independent variables were the initial moisture content (40-70\%), peptone concentration (2-5\%), and initial $\mathrm{pH}(\mathrm{pH} 6-8)$. The critical ranges of selected factors were determined by preliminary experiment using OFAT and screening by factorial design (data not shown). During the screening process of petiole used as a substrate, the initial moisture content (IMC), initial $\mathrm{pH}$, interaction of peptone, and $\mathrm{pH}$ were found to be significant. Thus, three factors were chosen for optimization. Screening was done to eliminate the insignificant factor. Table 1 lists the ranges and levels of the three independent variables with actual and coded levels of each factor. The lower and upper levels were coded as -1 and +1 ; the middle level was coded as 0 . A total of 18 runs with 4 central points were generated. The center points are usually repeated 4-6 times to determine the experimental error (pure error) and the reproducibility of the result. Three responses, red pigment $(\mathrm{AU} / \mathrm{g})$, biomass $(\mathrm{mg} / \mathrm{g})$ and glucose concentration $(\mu \mathrm{g} / \mathrm{g})$, were measured. The experiments were run in triplicate. The 
complete design matrix corresponding to the CCD design in terms of real and coded independent variables is displayed in Table 2.

\subsection{Validation Experiment}

The validation experiment was performed by conducting the experiment with the suggested optimal conditions of higher pigment.

\section{RESULTS AND DISCUSSION}

The statistical significance of the model equation was evaluated by the F-test analysis of variance (ANOVA). The ANOVA statistics for responses $\mathrm{Y}_{1}, \mathrm{Y}_{2}$, and $\mathrm{Y}_{3}$ were summarized in Table 3, 4, and 5, respectively. Multiple regression analyses of the response surface design were developed as in Equations 1, 2, and 3. In order to determine the optimal level of each variable for maximum production of red pigment and biomass, a 3D surface plot was designed as a function of two factors at a time, holding all other factors at a fixed level. This design was helpful for understanding both the main and the interaction of the two factors. The response values for the variables can be predicted from these plots.

Table 3: ANOVA analysis for red pigment production $\left(\mathrm{Y}_{1}\right)$

\begin{tabular}{|c|c|c|c|c|c|c|}
\hline Source & Sum of squares & DF & Mean square & F-value & Prob>F & \\
\hline Model & 4915.48 & 9 & 546.16 & 52.33 & $<0.0001$ & $\begin{array}{l}\text { Signi- } \\
\text { ficant }\end{array}$ \\
\hline $\begin{array}{l}\mathrm{X}_{1} \text { - Initial } \\
\text { moisture content }\end{array}$ & $9 \times 10^{3}$ & 1 & $9 \times 10^{3}$ & $8.6 \times 10^{4}$ & 0.9773 & \\
\hline $\begin{array}{l}\mathrm{X}_{2-} \text { Peptone } \\
\text { concentration }\end{array}$ & 26.9 & 1 & 26.9 & 2.58 & 0.1471 & \\
\hline $\begin{array}{l}\mathrm{X}_{3-} \text { Initial } \mathrm{pH} \\
\text { value }\end{array}$ & 126.74 & 1 & 126.74 & 12.14 & 0.0083 & \\
\hline $\mathrm{X}_{1} \mathrm{X}_{2}$ & 16.24 & 1 & 16.24 & 1.56 & 0.2475 & \\
\hline $\mathrm{X}_{1} \mathrm{X}_{3}$ & 0.18 & 1 & 0.18 & 0.017 & 0.8988 & \\
\hline $\mathrm{X}_{2} \mathrm{X}_{3}$ & 0.13 & 1 & 0.13 & 0.012 & 0.9156 & \\
\hline $\mathrm{X}_{1}^{2}$ & 44.47 & 1 & 44.47 & 4.26 & 0.0729 & \\
\hline $\mathrm{X}_{2}^{2}$ & 444.04 & 1 & 444.04 & 42.54 & 0.0002 & \\
\hline $\mathrm{X}_{3}^{2}$ & 1195.10 & 1 & 1195.10 & 114.51 & $<0.0001$ & \\
\hline Residual & 83.50 & 8 & 10.44 & & & \\
\hline Lack of fit & 76.15 & 5 & 15.23 & 6.22 & 0.0817 & $\begin{array}{l}\text { Not } \\
\text { signi- } \\
\text { ficant }\end{array}$ \\
\hline Pure error & 7.35 & 3 & 2.45 & & & \\
\hline & 0.9833 & & & & & \\
\hline Adeq precision & 18.345 & & & & & \\
\hline
\end{tabular}


Table 4: ANOVA analysis for biomass response $\left(\mathrm{Y}_{2}\right)$

\begin{tabular}{|c|c|c|c|c|c|c|}
\hline Source & Sum of squares & DF & Mean square & F-value & Prob>F & \\
\hline Model & $1.28 \times 10^{5}$ & 9 & 14169.99 & 7.63 & 0.0044 & $\begin{array}{l}\text { Signi- } \\
\text { ficant }\end{array}$ \\
\hline $\begin{array}{l}\mathrm{X}_{1} \text { - Initial } \\
\text { moisture content }\end{array}$ & 124.61 & 1 & 124.61 & 0.067 & 0.8022 & \\
\hline $\begin{array}{l}\mathrm{X}_{2} \text { - Peptone } \\
\text { concentration }\end{array}$ & 108.24 & 1 & 108.24 & 0.058 & 0.8153 & \\
\hline $\begin{array}{c}\mathrm{X}_{3}-\text { Initial } \mathrm{pH} \\
\text { value }\end{array}$ & 2982.53 & 1 & 2982.53 & 1.61 & 0.2408 & \\
\hline$X_{1} X_{2}$ & 296.46 & 1 & 296.46 & 0.16 & 0.7 & \\
\hline $\mathrm{X}_{1} \mathrm{X}_{3}$ & 5.95 & 1 & 5.95 & $3.2 \times 10^{3}$ & 0.9563 & \\
\hline $\mathrm{X}_{2} \mathrm{X}_{3}$ & 0.66 & 1 & 0.66 & $3.6 \times 10^{4}$ & 0.9854 & \\
\hline $\mathrm{X}_{1}^{2}$ & 4302 & 1 & 4302 & 2.32 & 0.1666 & \\
\hline $\mathrm{X}_{2}^{2}$ & 9802.12 & 1 & 9802.12 & 5.28 & 0.0507 & \\
\hline $\mathrm{X}_{3}^{2}$ & 25466.58 & 1 & 25466.58 & 13.71 & 0.0060 & \\
\hline Residual & 14864.29 & 8 & 1858.04 & & & \\
\hline Lack of fit & 13890.42 & 5 & 2778.08 & 8.56 & 0.0536 & $\begin{array}{l}\text { Not } \\
\text { signi- } \\
\text { ficant }\end{array}$ \\
\hline Pure error & 973.87 & 3 & 324.62 & & & \\
\hline & 0.8956 & & & & & \\
\hline Adeq precision & 7.105 & & & & & \\
\hline
\end{tabular}

Table 5: ANOVA analysis for glucose concentration response $\left(\mathrm{Y}_{3}\right)$

\begin{tabular}{|c|c|c|c|c|c|c|}
\hline Source & Sum of squares & DF & Mean square & F-value & Prob>F & \\
\hline Model & 90779.97 & 9 & 10086.66 & 91.77 & $<0.0001$ & $\begin{array}{l}\text { Signi- } \\
\text { ficant }\end{array}$ \\
\hline $\begin{array}{l}\mathrm{X}_{1} \text { - Initial } \\
\text { moisture content }\end{array}$ & 1.51 & 1 & 1.51 & 0.014 & 0.9095 & \\
\hline $\begin{array}{l}\mathrm{X}_{2} \text { - Peptone } \\
\text { concentration }\end{array}$ & 442.89 & 1 & 442.89 & 4.03 & 0.0796 & \\
\hline $\begin{array}{l}\mathrm{X}_{3-} \text { Initial } \mathrm{pH} \\
\text { value }\end{array}$ & 3997.20 & 1 & 3997.20 & 3637 & 0.0003 & \\
\hline $\mathrm{X}_{1} \mathrm{X}_{2}$ & 1074.62 & 1 & 1074.62 & 9.78 & 0.0141 & \\
\hline$X_{1} X_{3}$ & 7.57 & 1 & 7.57 & 0.069 & 0.7997 & \\
\hline $\mathrm{X}_{2} \mathrm{X}_{3}$ & 25.56 & 1 & 25.56 & 0.23 & 0.6425 & \\
\hline $\mathrm{X}_{1}{ }^{2}$ & 1516.91 & 1 & 1516.91 & 13.80 & 0.0059 & \\
\hline $\mathrm{X}_{2}^{2}$ & 9162.68 & 1 & 9162.68 & 83.37 & $<0.0001$ & \\
\hline $\mathrm{X}_{3}^{2}$ & 17555.18 & 1 & 17555.18 & 159.73 & $<0.0001$ & \\
\hline Residual & 879.26 & 8 & 109.91 & & & \\
\hline Lack of fit & 235.72 & 5 & 47.14 & 0.22 & 0.9319 & $\begin{array}{l}\text { Not } \\
\text { signi- } \\
\text { ficant }\end{array}$ \\
\hline Pure error & 643.54 & 3 & 214.51 & & & \\
\hline & 0.9904 & & & & & \\
\hline Adeq precision & 25.360 & & & & & \\
\hline
\end{tabular}




\subsection{Optimization of Red Pigment Production}

The second order polynomial equation model for prediction of the optimal point between the response variable (red pigment production) and the independent variables was expressed in Eqn. 1:

$$
\begin{gathered}
Y_{1}(\text { red pigment })=45.66-0.03 X_{1}+1.64 X_{2}+3.56 X_{3}-1.42 X_{1} X_{2}+0.15 X_{1} X_{3}+ \\
0.13 X_{2} X_{3}-405 X_{1}^{2}-12.80 X_{2}^{2}-21 X_{3}^{2}
\end{gathered}
$$

where $Y_{1}$ is the response for red pigment production, $X_{1}$ is the code for initial moisture content, $\mathrm{X}_{2}$ is for peptone concentration, $\mathrm{X}_{3}$ is for initial $\mathrm{pH}$ value.

Based on the ANOVA Table, as presented in Table 3, the quadratic model indicated that this model could be accepted to navigate the design space. The Model F-value of the response $\mathrm{Y}_{1}$ with the value 52.33 implies that the model was significant at $95 \%$ confidence level. The P-value was used as a tool to check the significance of each coefficient, which in turn designates the pattern of interaction between the factors. The smaller the P-value, the larger the significance of the coefficient was. As in Table 3, the P-values for the $\mathrm{Y}_{1}$ was $<0.0001$, which was less than 0.05 . Therefore, it can be concluded that the model terms were statistically significant. In addition, the main model terms indicated that the significant factor was the initial $\mathrm{pH}\left(\mathrm{X}_{3}\right)$, while the significant quadratic terms were peptone concentration $\left(\mathrm{X}_{2}^{2}\right)$ and initial $\mathrm{pH}\left(\mathrm{X}_{3}{ }^{2}\right)$. The lack of fit test with $\mathrm{P}$-value $(0.0817)$, which was not significant (p-value> 0.05 is not significant), supported the hypothesis that the model was satisfactorily fitted to the experiment data. The 'not significant' term of lack of fit is most-desired as a significant of lack of fit indicates the presence of the contribution in the regressor-response relationship that is not accounted for by the model [19]. The correlation coefficient $\left(\mathrm{R}^{2}\right)$ is a tool to identify the 'goodness of fit' between the experimental and the predicted values. Based on Table 3, the $\mathrm{R}^{2}$ for $\mathrm{Y}_{1}(0.9833)$ was found to be close to 1, which indicated the presence of a good relation between experimental and predicted values for red pigment $\left(Y_{1}\right)$. The adequate precision for $Y_{1}$ is 18.345 . These large values of adequate precision demonstrated that these quadratic models were significant for the process. The evaluation of residuals was analyzed to validate the adequacy of the model. A normal probability plot of the residuals for $Y_{1}$ is displayed in Fig. 1. Based on the figure, it clearly shows that the residuals distribution was nearly a straight line. Thus, it can be concluded that the errors were distributed evenly.

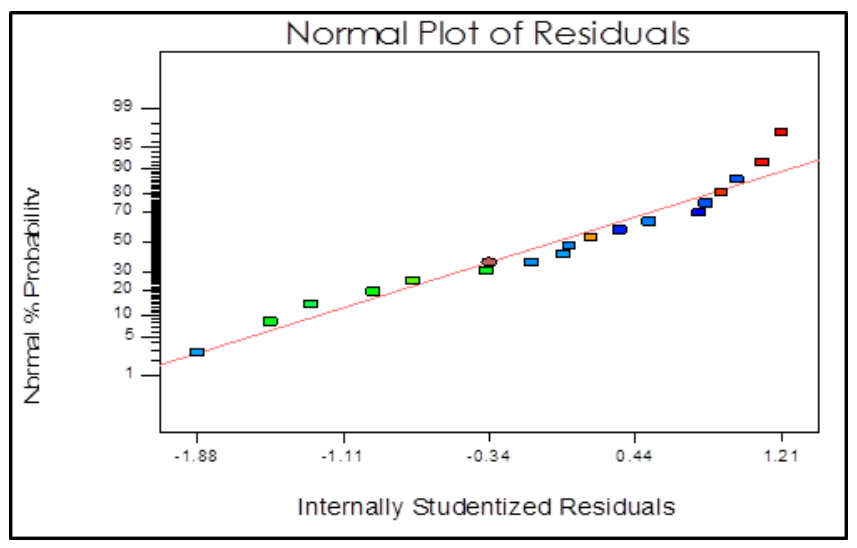

Fig. 1: Normal plot of residuals for red pigment production $\left(\mathrm{Y}_{1}\right)$. 
Figures $2 \mathrm{a}, 2 \mathrm{~b}$, and $2 \mathrm{c}$ show the 3D surface plots of the relationship between the main factors $\mathrm{X}_{1} \mathrm{X}_{2}$ (initial moisture content and peptone concentration), $\mathrm{X}_{1} \mathrm{X}_{3}$ (initial moisture content and initial $\mathrm{pH}$ ), and $\mathrm{X}_{2} \mathrm{X}_{3}$ (peptone concentration and initial $\mathrm{pH}$ ), respectively. In Fig. 2a, the increment of initial moisture content from low level $40 \%$ to $55 \%$ leads to the increase in red pigment to a maximum level. However, a further increase in the initial moisture content $(>55 \%)$ did not further increase the pigment. This result clearly shows that the red pigment decreased above and below the 55\% initial moisture content. The poor yield of red pigment at high moisture content $(>55 \%)$ was possibly due to the agglomeration of substrate, consequently reducing oxygen supply for the growth of Monascus. While, the decrease in red pigment at low moisture content was because of the insufficient nutrient supply due to the low nutrient salt dissolution [19].

A similar trend of effect on the response was observed for the initial moisture content and the initial $\mathrm{pH}$. An increase of the initial moisture content and initial $\mathrm{pH}$, up to the optimum point, maximized the red pigment production and a further increase of the factors decreased the red pigment, as shown in Fig. $2 b$. This reaction process was in agreement with Orozco and Kilikian [20] in which changing the $\mathrm{pH}$ value of the medium from $\mathrm{pH} 5.5$ to $\mathrm{pH}$ 8 , caused the drastic excretion of the red pigment. In addition, they also claimed that the best condition for red pigment production was at alkaline medium $(\mathrm{pH} 8.0 \mathrm{or} \mathrm{pH} 8.5$ ). Between these two $\mathrm{pH}$ values, $\mathrm{pH} 8$ had been chosen to be the best condition due to the maximum yield of red pigment production.

The interaction effect of the peptone concentration with initial $\mathrm{pH}$ as shown in Fig. 2c clearly suggested the best combination for production of red pigment. An increase in the peptone concentration with initial $\mathrm{pH}$, optimized the red pigment gradually. However, at higher peptone concentration $(>3.5 \%)$ and higher initial $\mathrm{pH}(>\mathrm{pH} 8)$, the pattern is reversed. The decrease in yield may due to excessive nutrients provided in the medium that became toxic and inhibited the red pigment production. Therefore, the optimum conditions for maximum red pigment production were obtained at the initial moisture content of $55 \%$, peptone concentration of $3.5 \%$, and initial $\mathrm{pH}$ value of 8 . The maximum red pigment achieved was $47.9 \mathrm{AU} / \mathrm{g}$.

\subsection{Optimization of Biomass Production}

Based on the experimental results and regression analysis, a quadratic polynomial equation was developed to determine the relationship between the biomass of Monascus purpureus and the factors. The model of coded units can be stated as in Eqn. 2:

$$
\begin{gathered}
Y_{2}(\text { biomass })=382.75+3.53 X_{1}+3.29 X_{2}+17.27 X_{3}-6.09 X_{1} X_{2}-0.86 X_{1} X_{3}- \\
0.29 X_{2} X_{3}-39.85 X_{1}^{2}-60.15 X_{2}^{2}-96.95 X_{3}^{2}
\end{gathered}
$$

where $Y_{2}$ is the response for biomass production, $\mathrm{X}_{1}$ is the code for initial moisture content, $\mathrm{X}_{2}$ is for peptone concentration, and $\mathrm{X}_{3}$ is for initial $\mathrm{pH}$ value.

From the analysis of variance (ANOVA) as presented in Table 4, the model for biomass was highly significant (P-value, 0.0044) and the $\mathrm{R}^{2}(0.8956)$ was relatively good, as evidenced by the significance of the model. There was no significance of a single factor or interaction between factors that influenced the biomass production, however, the quadratic terms of initial $\mathrm{pH}$ value was found to be significant. Furthermore, the lack of fit was not significant with P-value of $0.0536(>0.05)$, indicating that the experimental data obtained fitted well with the model. 

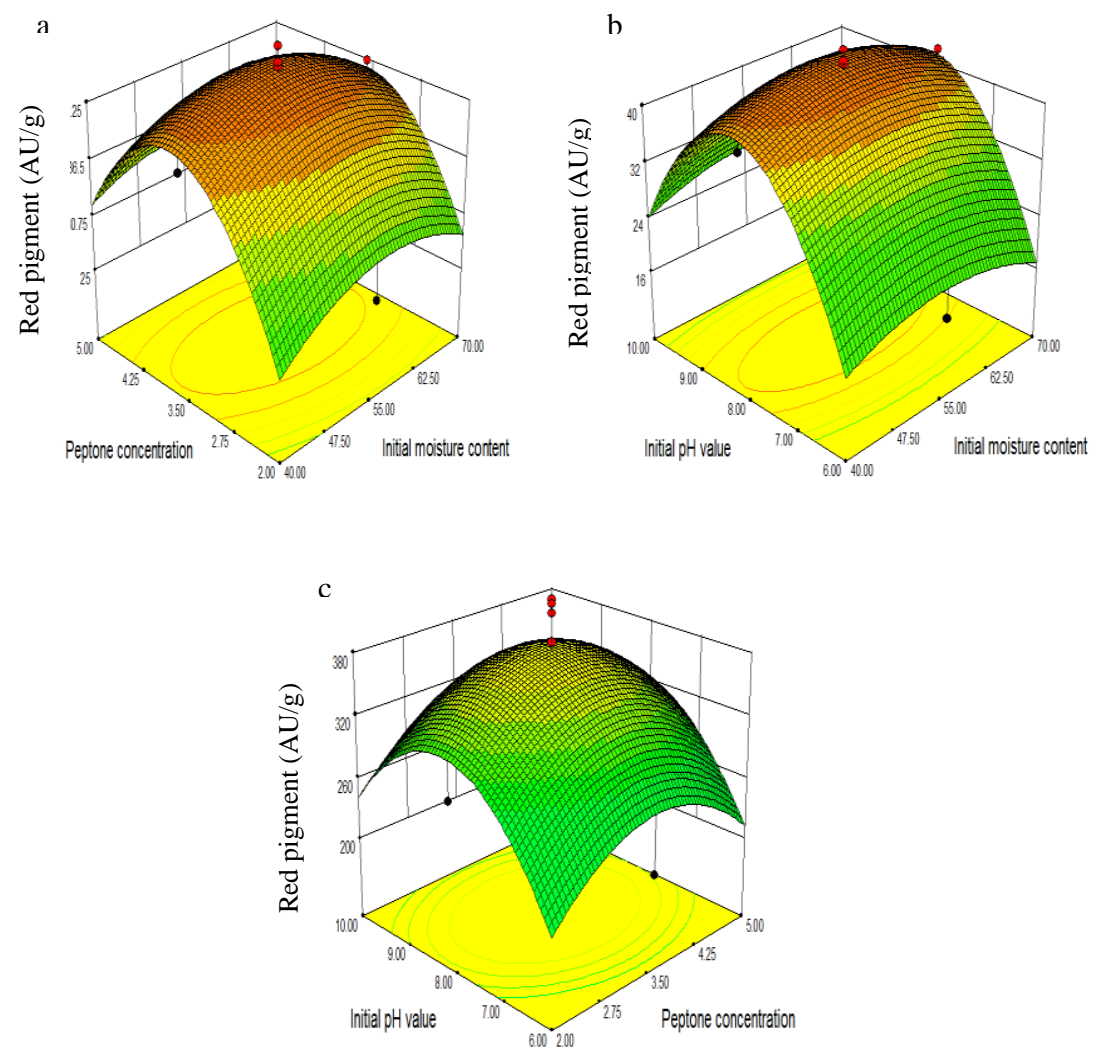

Fig. 2: Response surface curve showing combined effect between the main factors: (a) initial moisture content $\left(\mathrm{X}_{1}\right)$ and peptone concentration $\left(\mathrm{X}_{2}\right)$, (b) initial moisture content $\left(\mathrm{X}_{1}\right)$ and initial $\mathrm{pH}$ value $\left(\mathrm{X}_{3}\right)$, (c) peptone concentration $\left(\mathrm{X}_{2}\right)$ and initial $\mathrm{pH}$ value $\left(\mathrm{X}_{3}\right)$.

The residual analysis was carried out for the confirmation of the adequacy of the model. This was done by observing the normal probability plot of the residual in Fig. 3 where the residuals were on a straight line, suggesting that the errors were distributed evenly.

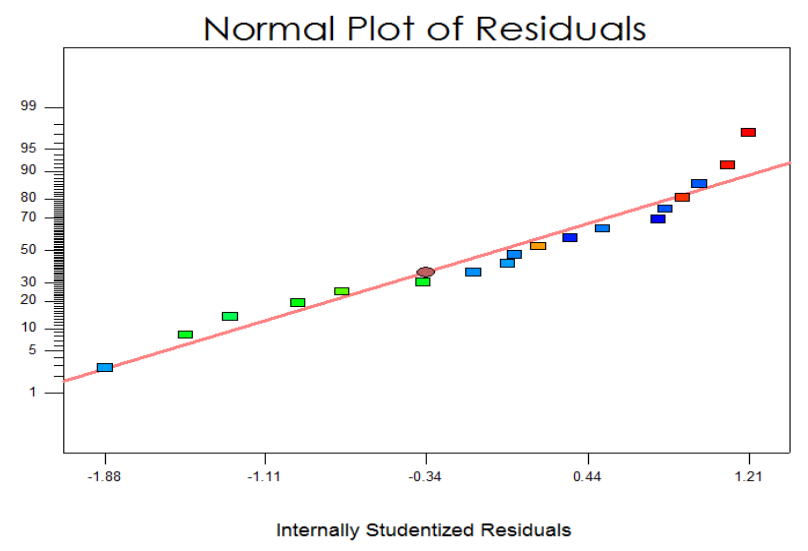

Fig. 3: Normal plot of residuals for biomass response $\left(\mathrm{Y}_{2}\right)$.

Figures $4 \mathrm{a}, 4 \mathrm{~b}$, and $4 \mathrm{c}$ show the 3D surface plots of biomass responses after combining the effect of the main factors. The effect of the initial moisture content and peptone concentration on the biomass is shown in Fig. 4a. An increase of initial moisture content with peptone concentration up to the optimum point increased the fungal biomass to a maximum level and a further increase in the initial moisture content and peptone 
concentration did not further increase the trend. This finding was supported by Krishna [21], who stated that the low initial moisture content could reduce nutrient diffusion consequently affecting the growth of the Monascus. However, if the initial moisture content is too high, water will occupy the voids where airflow is required for fungal growth.

Increased factors of initial moisture content and initial $\mathrm{pH}$ up to the optimum point, maximized the biomass production (Fig. 4b). From the 3D plot, it was obviously shown that Monascus was grown successfully at $\mathrm{pH} 8$ indicating that the biomass achieved the maximum yield. However, the fungal biomass production started to decrease with a further increase of initial $\mathrm{pH}(>\mathrm{pH} 8)$ of substrate.

The interaction effect of the peptone concentration with initial $\mathrm{pH}$ in Fig. 4c clearly suggested the best combination for the production of fungal biomass. An increase in the peptone concentration and initial $\mathrm{pH}$ optimized the biomass gradually but at higher peptone concentration and initial $\mathrm{pH}$, the pattern is reversed. It was studied that nitrogen is the major element of cell membranes and nucleic acid, therefore supplying nitrogen sources to the medium may facilitate the growth of the fungus. However, if the nitrogen concentration is too high ( $>3.5 \%$ ), it might inhibit the fungal growth. Therefore, the optimum biomass was observed at the initial moisture content of $55 \%$, peptone concentration of $3.5 \%$, and initial $\mathrm{pH}$ of substrate of $\mathrm{pH}$ 8. The maximum biomass achieved was $430.8 \mathrm{mg}$ cell dry weight/g dry matter.
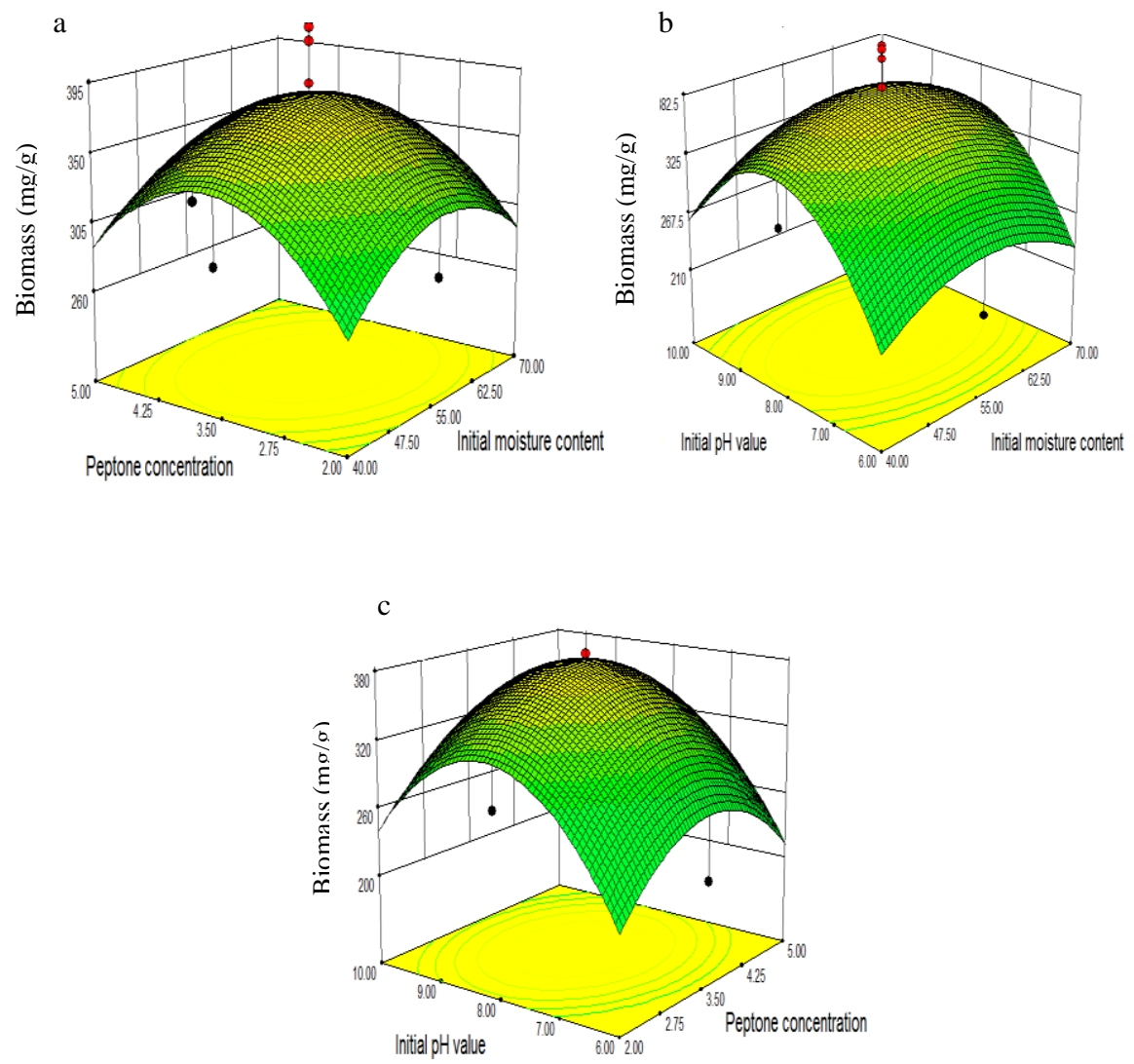

Fig. 4: Response surface curve showing combined effect between the main factors:

(a) initial moisture content $\left(\mathrm{X}_{1}\right)$ and peptone concentration $\left(\mathrm{X}_{2}\right)$,

(b) initial moisture content $\left(\mathrm{X}_{1}\right)$ and initial $\mathrm{pH}$ value $\left(\mathrm{X}_{3}\right)$,

(c) peptone concentration $\left(\mathrm{X}_{2}\right)$ and initial $\mathrm{pH}$ value $\left(\mathrm{X}_{3}\right)$. 


\subsection{Glucose Concentration}

On the glucose consumption, a second order polynomial can be obtained by the Design Expert. Multiple regression equations (in term of coded factors) were represented in Eqn. 3:

$$
\begin{aligned}
Y_{1}(\text { glucose concentration })= & 130.65-0.39 X_{1}-6.66 X_{2}-19.99 X_{3}+11.59 X_{1} X_{2}- \\
& 0.97 X_{1} X_{3}-1.79 X_{2} X_{3}+23.66 X_{1}^{2}+58.15 X_{2}^{2}+80.49 X_{3}^{2}
\end{aligned}
$$

where $\mathrm{Y}_{3}$ is the response for glucose concentration, $\mathrm{X}_{1}$ is the code for initial moisture content, $\mathrm{X}_{2}$ is for peptone concentration, $\mathrm{X}_{3}$ is for initial $\mathrm{pH}$ value.

The ANOVA Table implies that the model was significant with the F-value of 91.77 (Table 5). The P-value $(<0.0001)$ was less than 0.05 , which indicated the model terms were highly significant. In addition, the main model terms indicated that the significant factor was initial $\mathrm{pH}$ value $\left(\mathrm{X}_{3}\right)$ and the interaction terms were found to exist between initial moisture content $\left(\mathrm{X}_{1}\right)$ with peptone concentration $\left(\mathrm{X}_{2}\right)$. While, the significant quadratic terms were initial moisture content $\left(\mathrm{X}_{1}^{2}\right)$, peptone concentration $\left(\mathrm{X}_{2}^{2}\right)$, and initial $\mathrm{pH}$ value $\left(\mathrm{X}_{3}{ }^{2}\right)$. The lack of fit value of 0.22 confirmed that the lack of fit was not significant, relative to the pure error when $p$-value was 0.9319 and $>0.05$. The insignificant lack of fit demonstrates the good predictability of the model. In addition, the value of $\mathrm{R}^{2}$ was 0.9914 , indicating that the model was fitted and explains $99.14 \%$ of the variability in glucose concentration. The high values of adequate precision with the value of 25.360 demonstrated that these quadratic models were significant for the process.

Figure 5 displays the normal plot of residuals of response $\mathrm{Y}_{3}$ glucose concentration. It was obviously shown that the points cluster around the diagonal line which indicated the good fit of the model.

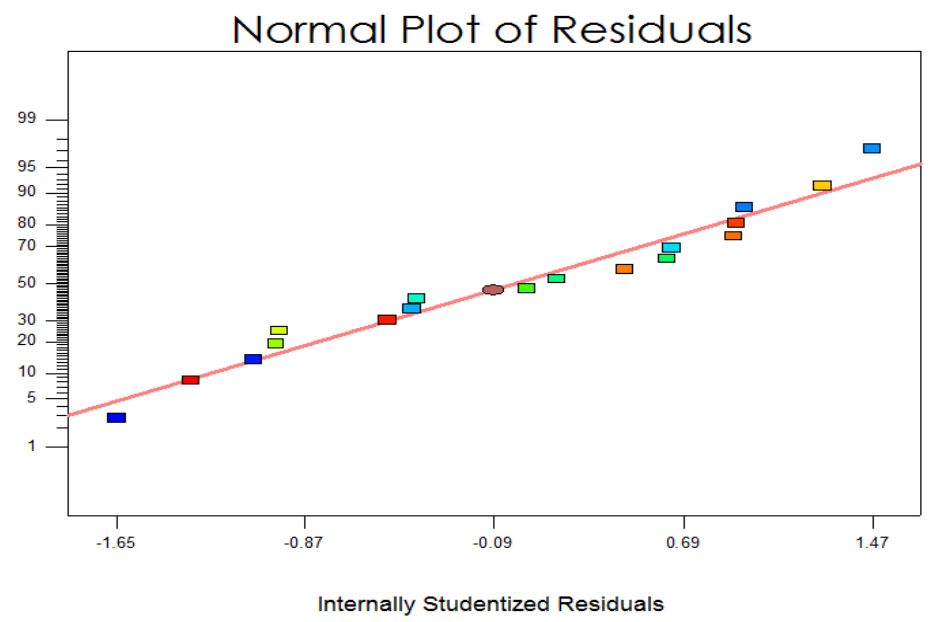

Fig. 5: Normal plot of residuals for glucose concentration response $\left(\mathrm{Y}_{3}\right)$.

Figures $6 \mathrm{a}, 6 \mathrm{~b}$, and $6 \mathrm{c}$ show the $3 \mathrm{D}$ surface plots of glucose concentration response after combining the effect between the main factors. From the figure, it was observed that the glucose was decreased when the initial moisture content, peptone concentration and initial $\mathrm{pH}$ value were 55\%, 3.5\% and $\mathrm{pH} \mathrm{8}$, respectively. The 3D surface plots of glucose concentration were totally different with the previous figures (Figures 2a, 2b, 2c, 4a, 4b, and $4 \mathrm{c})$. The glucose concentration decreased when the fungal biomass and red pigment production achieved the maximum yield. This phenomenon suggested that the rapid consumption of glucose by Monascus caused the depletion of glucose, consequently 
resulting in an insufficient glucose supply that reached its supply limitation [22]. The lowest final glucose concentration of $114.73 \mu \mathrm{g} / \mathrm{g}$ was obtained.
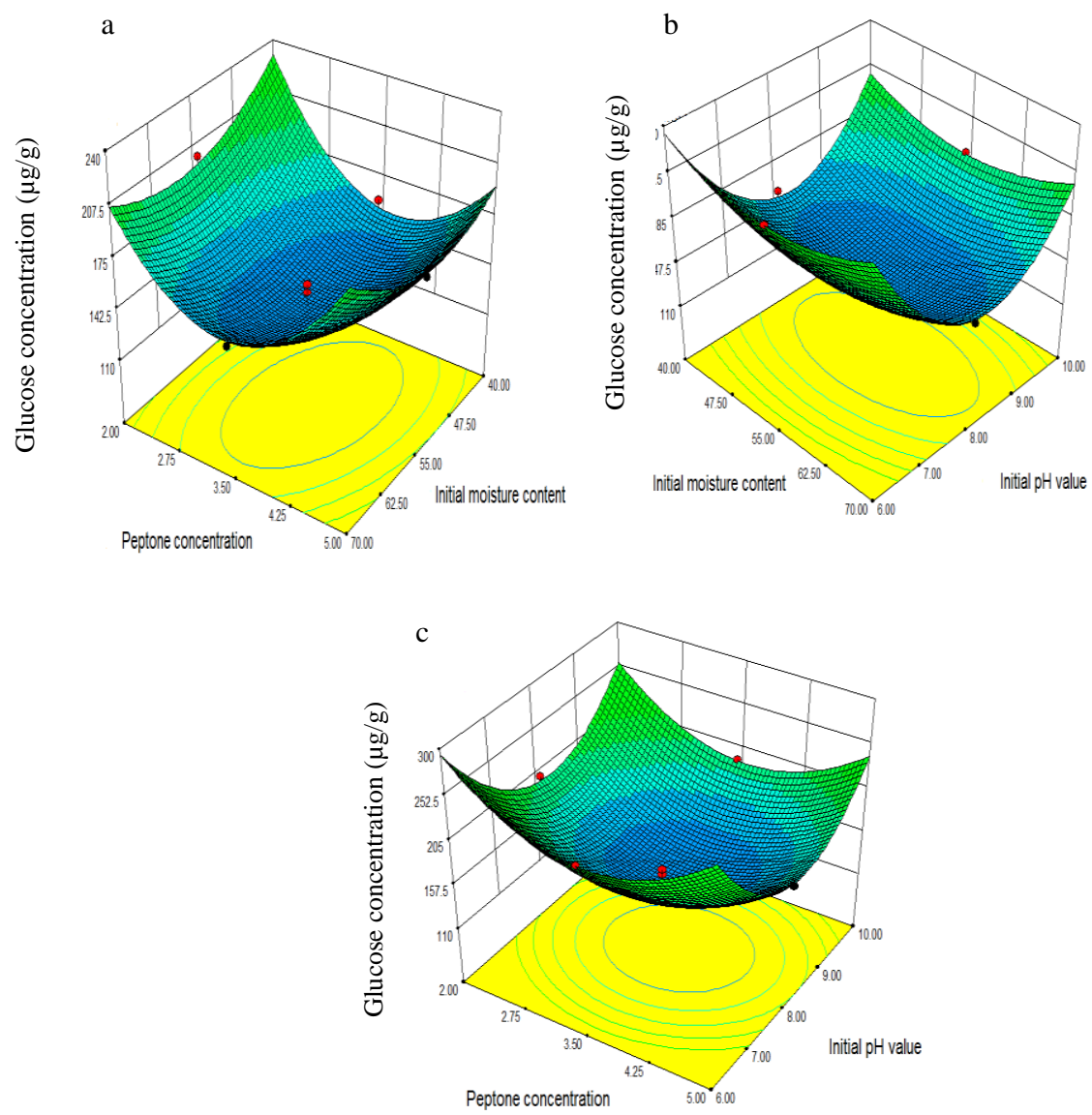

Fig. 6: Response surface curve showing combined effect between the main factors:

(a) initial moisture content $\left(\mathrm{X}_{1}\right)$ and peptone concentration $\left(\mathrm{X}_{2}\right)$,

(d) initial moisture content $\left(\mathrm{X}_{1}\right)$ and initial $\mathrm{pH}$ value $\left(\mathrm{X}_{3}\right)$,

(e) peptone concentration $\left(\mathrm{X}_{2}\right)$ and initial $\mathrm{pH}$ value $\left(\mathrm{X}_{3}\right)$.

\subsection{Validation}

In order to confirm the optimization of red pigment production by Monascus purpureus FTC 5356, an experiment was performed under the predicted optimal conditions. This experiment was conducted in triplicate. Under these suggested conditions, the predicted optimal values of the variables were $56 \%$ initial moisture content, $3.5 \%$ peptone, and $\mathrm{pH}$ 8.2. The prediction of the total red pigment was $45.85 \mathrm{AU} / \mathrm{g}$ and the actual value obtained through the triplicate experiments was $46.03 \mathrm{AU} / \mathrm{g}$, as shown in Table 6. The percentage error calculated based on the Eqn. 4 was $0.39 \%$. Therefore, the experimental results agreed well with the model predicted values.

$$
\text { Percentage error }=\frac{(\text { Experimental value }- \text { predicted value })}{\text { Experimental value }} \times 100 \%
$$


Table 6: Optimum factors of RSM on red pigment

\begin{tabular}{lcccc}
\hline Factor & Value & $\begin{array}{c}\text { Predicted } \\
(\mathbf{A U} / \mathbf{g})\end{array}$ & $\begin{array}{c}\text { Actual } \\
(\mathbf{A U} / \mathbf{g})\end{array}$ & $\begin{array}{c}\text { Percentage } \\
\text { error }(\%)\end{array}$ \\
\hline $\begin{array}{l}\text { Initial moisture } \\
\text { content (\%) }\end{array}$ & 56 & & & \\
$\begin{array}{l}\text { Peptone (\%) } \\
\mathrm{pH}\end{array}$ & 3.5 & 45.85 & 46.03 & 0.39 \\
\hline
\end{tabular}

\section{CONCLUSION}

This study shows that response surface methodology is a fast and error-free approach for optimization of media composition to obtain the best performance of red pigment production and biomass. Besides, an interaction study among all the components was an additional advantage of employing RSM. Results obtained from response surface methodology critically point out the importance of initial $\mathrm{pH}$ value of the substrate for red pigment production as well for the fungal biomass.

\section{ACKNOWLEDGEMENT}

This work was funded by research grant granted by Ministry of Higher Education of Malaysia under FRGS grant no. RDU 150105.

\section{REFERENCES}

[1] Hakim MA. (2015) Food coloring analysis in four selected dishes. American J. Biology and Life Sci., 395: 187-189.

[2] Miyake T, Isato K, Nobuyuki N, Sammoto H. (2008) Analysis of pigment composition in various Monascus cultures. Food Sci. and Technol. Res., 14: 194-197.

[3] Hamid NF, Said FM. (2016) Factorial design screening for the red pigment production by Monascus purpureus FTC 5356. Jurnal Teknologi, 78(11-2): 13-17.

[4] Poorniammal R, Gunasekaran G, Murugesan R. (2015) Statistical optimization of culture medium for yellow pigment production by Thermomyces sp. J. Appl. and Natural Sci., 7(1): 203-210.

[5] Ren X, He L, Cheng J, Chang J. (2014) Optimization of the solid state fermentation and properties of a polysaccharide from Paecilomyces cicadae (miquel) Samson and its antioxidant activities in vitro. Plos One, 9(2): e87578.

[6] Ajdari Z, Ebrahimpour A, Manan MA, Ajdari D, Abbasiliasi S, Hamid M, Mohamad R, Ariff AB. (2012) A statistical modeling study by response surface methodology and artificial neural networks on medium optimization for Monascus purpureus FTC 5391 sporulation. Minerva Biotech., 24: 71-81.

[7] Dikshit R, Tallapragada P. (2016) Statistical optimization of lovastatin and confirmation of nonexistence of citrinin under solid state fermentation by Monascus sanguineus. J. Food and Drug Analysis, 24: 433-440.

[8] Sani J, Montira N, Panit K, Taweerat V, Anan T. (2013) Statistical optimization for monakolin $\mathrm{K}$ and yellow pigment production and citrinin reduction by Monascus purpureus in solid state fermentation. J. Biotechnol. Microbiol., 23(3): 364-374.

[9] Prajapati VS, Soni N, Trivedi UB, Patel KC. (2013) An enhancement of red pigment production by submerged culture of Monascus purpureus MTCC 410 employing statistical methodology. Biocatalyst and Agricultural Biotechnol., 3: 140-145. 
[10] Dikshit R, Tallapragada P. (2014) Collective effects of stress on optimization of pigment production by Monascus purpureus. Chiang Mai J. Sci., 41(3): 524-530.

[11] Ahmad M, Panda BP. (2014) Optimization of red pigment production by Monascus purpureus MTCC 369 under solid state fermentation using response surface methodology. Songklanakarin J. Sci. and Technol., 36(4): 439-444.

[12] Said FBM. (2010) Monascus ruber ICMP 15220 fermentation for the production of pigment. $\mathrm{PhD}$ Thesis. Massey University. New Zealand.

[13] Johns MR, Stuart and DM. (1991) Production of pigments by Monascus purpureus in solid culture. J. Industrial Microbiol., 8: 23-28.

[14] Lin TF, Demain AL. (1992) Fermentation of water soluble Monascus red pigments by biological and semi synthetic processes. J. Industrial Microbiol. 9: 173-179.

[15] Miller GL. (1959) Use of dinitrosalicylic acid reagent for determination of reducing sugar. Anal. Chem., 31: 426-428.

[16] Roopesh K, Ramachandran S, Nampoothiri KM, Szakacs G, Pandey A. (2006) Comparison of phytase production of wheat bran and oil cakes in solid state fermentation by Mucor racemosus. Bioresource Technol., 97: 506-511.

[17] Swift MJ. (1973) The estimation of mycelial biomass by determination of the hexosamine content of wood tissue decayed by fungi. Soil Biology Biochem., 55: 321-332.

[18] Babitha S, Soccol CR, Pandey A. (2006) Jackfruit seed-A novel substrate for the production of Monascus pigments through solid state fermentation. Food Technol. Biotechnol. 44: 465471.

[19] Noordin MY, Venkatesh VC, Sharif S, Elting S, Abdullah A. (2004) Application of response surface methodology in describing the performance of coated carbide tools when turning AISI 1045 steel. J. Material Processing Technol., 145: 46-58.

[20] Orozco SFB, Kilikian BV. (2008) Effect of $\mathrm{pH}$ on citrinin and red pigment production by Monascus purpureus CCT3802. World J. Microbiol. and Biotechnol., 24: 263-268.

[21] Krishna C. (2005) Solid state fermentation system-An Overview. Critical review in Biotechnol., 25(1-2): 1-30.

[22] Babitha S, Soccol CR, Pandey A. (2007) Solid state fermentation for the production of Monascus pigment from jackfruit seed. Bioresource Technol., 98: 1554-1560. 